\title{
Variation Among Populations of the Troglobitic Amphipod Crustacean Crangonyx Antennatus Packard (Crangonyctidae) Living in Different Habitats II. Population Distribution
}

\author{
Gary W. Dickson
}

\begin{abstract}
SUMMARY
Population densities and factors affecting the distribution of the troglobtic (i.e., obligatory cavernicole) amphipod Crangonyx antennatus were examined in two distinct aquatic habitats. Observations were made seasonally for one year in six Lee Co., Virginia (U.S.A.) caves, three with mud-bottom pools and three with gravel-bottom streams. Pool habitats were found to contain greater $C$. antennatus densities than stream habitats, while the highest seasonal densities were recorded in August. Availability of food is considered to be the major factor allowing these increased population densities. The population distribution of $C$. antennatus was not found to be related to current velocity, water depth, macro-detrital food sources or isopods densities in both pool and stream habitats. The distribution of $C$. antennatus was observed to be related to substrate type. Substrate selection appeared to be passive in five of the amphipod populations, while in one cave, substrate selection may be influenced by competitive interactions. The fact that population distributions were not related to environmental parameters which differ markledy between habitats indicates that this troglobitic species retains ecological flexibility.
\end{abstract}

\section{INTRODUCTION}

The distribution of freshwater amphipods has been reported to be influenced by several environmental parameters, including food sources (Marzolf, 1965, 1966; Kaushik and Hynes, 1968;

*Department of Biological Sciences. Old Dominion University. Norfolk, Virginia 23508, U.S.A. Present address: CIBA-GEIGY Corporation. Agricultural Division. P.O. Box 18300. Greensboro, N.C. 27419 - USA. 
1970; Dickson and Kirk, 1976), current velocity (Minckley and Cole, 1963; Culver, 1971), substrate (Minckley and Cole, 1963; Marzolf, 1965), and the presence of predators (Culver, 1973b, 1975) and competitive species (Culver, 1970, 1973a, 1975). Determinations of the relative importance of factors which effect amphipod distribution present a complex problem in most epigean habitats. On the other hand, cave systems, because of their ecological simplicity provide attractive areas in which to conduct a multifactorial distribution study on amphipod populations. Caves are relatively constant, allochthonous ecosystems in which species diversity and population sizes are generally quite small and community structure is relatively simple in comparison to epigean ecosystems.

Crangonix antennatus is one of the most common and widespread troglobitic (i.e., obligatory cavernicole) amphipod species in the southern Appalachians of the eastern United States (Holsinger, 1969, 1972). Populations of this species in Lee Co., Virginia are relativly large and found in two distinct cave habitats, mud-bottom pools and gravel-bottom streams. Amphipod populations living in these two habitats were found to exhibit differences in morphology, population dynamics and behavior (Dickson, 1976, 1977a, 1977b). The presence of two distinct habitats allows a comparison of the importance of environmental parameters on the distribuion of C. antennatus under both lentic and lotic conditions.

In the present study, the distribution of C. antennatus populaions from mud-bottom pools and gravel-bottom streams was examined to determine: 1) population densities in relation to season, habitat and individual cave locations, and 2) the relative importance of major environmental parameters in the distribution of $C$. antennatus in habitats and individual caves.

\section{METHODS AND MATERIALS}

During 1974 and 1975 populations of C. antennatus were sampled seasonally in six Lee Co., Virginia caves, of which three contained mud-bottom pool habitats (Sweet Potato, Molly Wagle and Roadside No. 1 caves) and three contained gravel-bottom stream habitats (Gallohan No. 2, Cope and Spangler caves).

The benthic substrate in mud-bottom pools is characterized by mud sediments which contain large populations of bacteria and fungi, in contrast to stream habitats which contain bottom gravels and sparse organic sediments with small microbial populations (Dickson, 1975; Dickson and Kirk, 1976). In the caves investigated, $C$. antennatus was the only amphipod species observed, but two species of potentially competitive isopods were 
present. One isopod, Caecidotea recurvata, was found in four of the caves sampled (Gallohan No. 2, Cope, Spangler and Sweet Potato caves), whereas the other, Lirceus usdagalun, was found only in Gallohan No. 2 Cave. In general, mud-bottom pool habitats contain greater quantities of available food (non-particulate), a more homogeneous substrate and lower population densities of potentially competitive isopod species than gravel-bottom streams habitats.

Ten sample plots of $0.09 \mathrm{~m}^{2}$ were randomly selected in stream and pool areas of the six caves during each of four seasonal sampling periods. The number of C. antennatus observed within each sample site was recorded, including any present in the top $5 \mathrm{~cm}$ of gravels in stream habitats. In addition, five major environmental parameters were recorded for each sample site according to the method presented in Table 1. These factors include substrate type, current velocity, food, water depth and number of isopods. A mulivariate statistical analysis was conducted utilizing a Statistical Analysis System (Barr et al., 1976) computer program to determine the importance of the recorded environmental factors on the distribution of C. antennaus.

Table 1. Categorization of the five environmental parameters recorded in association with $C$. antennatus within each sample site.

Substrate - mud, flowstone, small gravel $(<3 \mathrm{~mm})$, large gravel $(3-15 \mathrm{~mm}$ ), bedrock.

Current velocity* - none present, $0.5-2 \mathrm{~cm} / \mathrm{sec}, 2-4 \mathrm{~cm} / \mathrm{sec},>4 \mathrm{~cm} / \mathrm{sec}$.

Depth - average depth $(\mathrm{cm})$.

Food - none present, leaf-wood detritus, small mammal dung.

Isopods - number of Caecidotea recurvata and Lirceus usdagalun.

*Current velocity determined by calibrated pitot tube.

\section{RESULTS}

The population density of C. antennatus in the six caves investigated (Fig. 1) was found to differ significantly (Table 2), with Roadside No. 1 Cave containing the greatest population density and Gallohan No. 2 Cave the lowest. Significant differences in population densities were also noted between habitats and between seasons (Table 2). Mudbottom pool habitats contained greater C. antennatus densities than gravel-bottom stream habitats, with the highest seasonal densities recorded in August.

Substrate type was the only parameter of those analysed to show a significant relationship with the distribution of C. an- 
C. antennatus -

C. recurvata $\cdots \diamond \cdots$

ㄴ.. usdagalun ……

Gallohan 2

Spangler

Cope

Sweet Potato

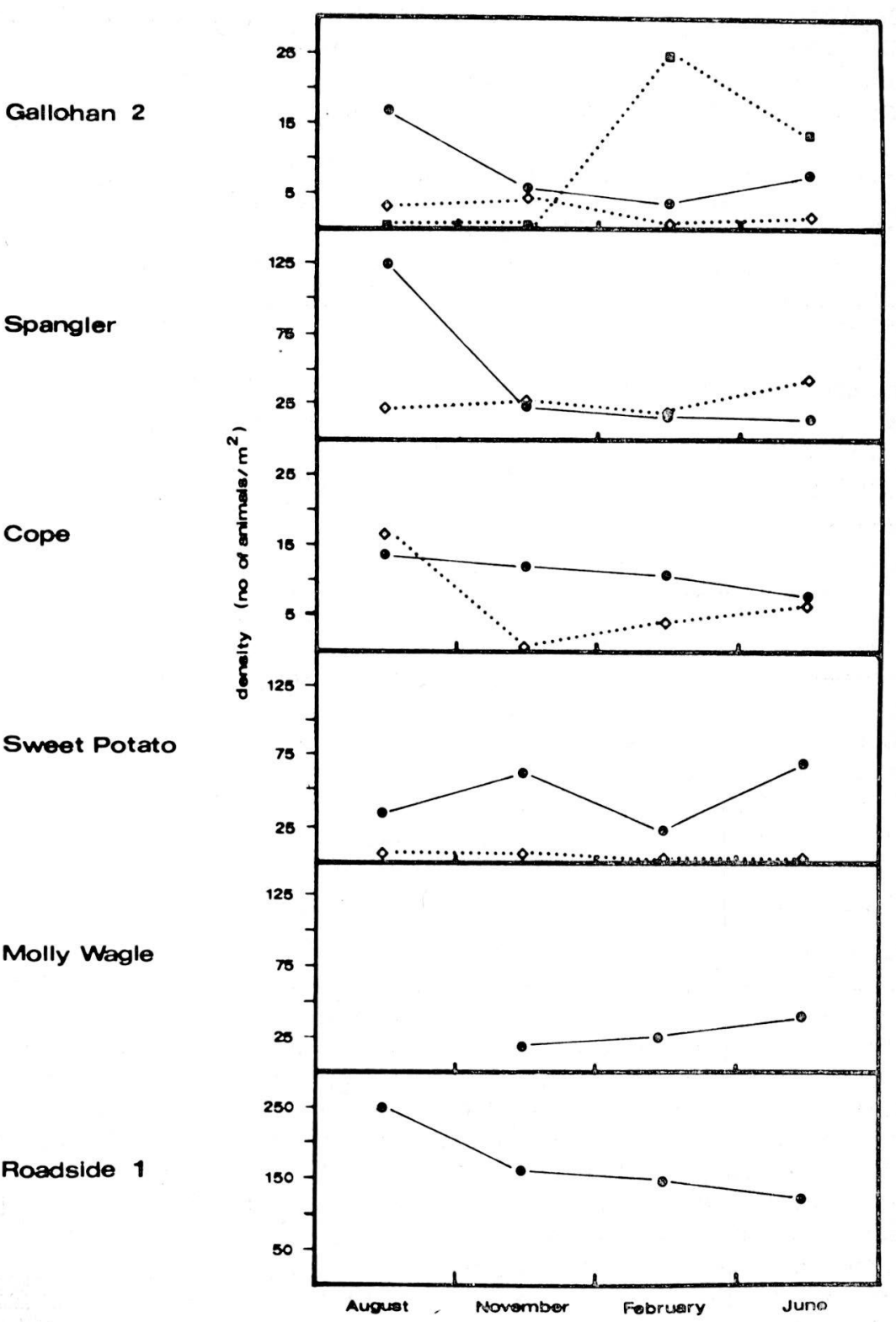

Molly Wagle

Roadside 1

Figure 1. Population density $\left(n o . / \mathrm{m}^{2}\right)$ of $C$. antennatus in each cave during seasonal collection periods. Broken lines indicate population densities of the isopod species, $L$. usdagalun and $C$. recurvata. Note density scale change. 
tennatus (Table 3). This substrate effect was observed both within habitats and in individual cave populations.

In five of the six caves investigated, C. antennatus densities were greatest on the most common substrate present (Table 4). In Spangler Cave, however, the greatest number of amphipods were associated with large gravel areas rather than the most common substrate, bedrock (Table 4).

Table 2. The mean number of $C$. antennatus observed in sample plots $(0.09$ $\mathrm{m}^{2}$ ) within caves, habitats and seasons. Significance between amphipod densities determined by analysis of variance.

\begin{tabular}{lcccc}
\hline Cave & N & X & S.D. & P \\
\hline Gallohan No. 2 & 40 & 0.77 & 1.03 & \\
Cope & 40 & 0.95 & 1.39 & \\
Spangler & 40 & 4.38 & 9.75 & $<.01$ \\
Sweet Potato & 40 & 4.38 & 4.34 & \\
Molly Wagle & 30 & 2.63 & 1.65 & \\
Roadside No. 1 & 40 & 7.75 & 2.33 & \\
Habitat & & & & \\
Mud-bottom pool & 110 & 5.13 & 3.72 & \\
Gravel-bottom stream & 120 & 2.09 & 5.90 & \\
Season & & & & \\
Summer & 50 & 5.80 & 9.09 & \\
Fall & 60 & 3.31 & 3.85 & \\
Winter & 60 & 2.30 & 2.53 & \\
Spring & 60 & 3.18 & 3.25 & \\
\hline
\end{tabular}

\section{DISCUSSION}

The greater population densities of $C$. antennatus in caves containing mud-bottom pool habitats (Fig. 1, Table 2) probably results from the presence of larger food supplies, the lack of competitors and the absence of seasonal flooding.

The observed ingestion of mud sediments by $C$. antenntus in mudbottom pool habitats (Dickson and Holsinger, unpublished observations) apparently involves the utilization of endemic microorganism as a major source of nutrition (Dickson, 1979). The significantly larger microbial populations associated with pool sediments (Dickson, 1975; Dickson and Kirk, 1976) represent a greater nutritional base than is available in the stream habitats, thus allowing larger amphipod populations.

The smaller and more sporadic food input (allochthonous detritus) in cave stream habitats, combined with the presence of isopod populations, could lower $C$. antennatus densities through 
limited food supplies and competitive interactions. The smallest amphipod densities were found in Gallohan No. 2 Caves which contains populations of the two potentially competitive isopods and, in addition, has the lowest food rating (Dickson, 1977) of the six caves studied.

Seasonal flooding was found to be a significant environmental perturbation important in controlling population densities of cave crustaceans in stream habitats (Culver, 1971). Both Cope and Spangler caves were observed to flood during the year studied. Although there is evidence that stream populations of $C$. antennatus may be better adapted to resist stream washout (Dickson, 1977b), full scale flooding probably acts as a factor in reducing population densities. Perturbation in mud-bottom pool habitats due to loss of water during periodic droughts does not appear to affect the population density of C. antennatus, however. This species can survive by burrowing into the damp mud substrate (Holsinger and Dickson, 1977).

The higher C. antennatus population densities recorded in $\mathrm{Au}-$ gust in four of the six caves (Fig. 1, Table 2) is thought to be due primarily to greater availability of food sources. Detrital material transported into the stream habitats during spring rains and flooding becomes an important food source for C. antennatus through microbial colonization and degradation over the summer months. Mud-bottom pool habitats receive organic materials through a leaching process involving surface water passing through soil into caves. The combination of increased spring rainfall and greater surface productivity probably causes a greater influx of soluble organics into these habitats.

Three environmental parameters, macro-detrital food sources, current velocity and potentially competitive isopods were believed initially to be important in the distribution of C. antennatus. But the present multivariate analysis did not reveal any

Table 3. Relationship between $C$. antennatus number and each of the five recorded environmental parameters within individual caves and habitats. Significance is determined by F-test in conjunction with the multivariate analysis described in Barr et al. (1976).

\begin{tabular}{lcc}
\hline & Within caves & Within habitats \\
\hline Substrate & + & + \\
Current velocity & 0 & 0 \\
Depth & 0 & 0 \\
Food & 0 & 0 \\
Isopods & 0 & 0 \\
\hline
\end{tabular}

$+=\mathrm{P}<.001$

$0=\mathrm{P}>.05$ 
significant relationship between these factors and amphipod numbers (Table 3). Evidence from the present study and from previous observations (Dickson, 1975; Dickson and Kirk, 1976) indicates that microbial populations associated with benthic sediments apparently constitute the major food source for C. antennatus in both stream and pool habitats. Under these circumstances population distributions would not exhibit a significant relationship with macro-detrital sources.

Because C. antennatus inhabits both stream and pool areas, adaptation to current velocity under lotic conditions would be expected and has been observed (Dickson, 1977b). The fact that current velocity did not affect the distribution of amphipod populations may be attributed to this adaptation. A large increase in current velocity associated with heavy rains and flooding, however, is assumed to cause temporary shifts in population distributions.

The lack of a significant relationship between $C$. antennatus numbers and isopods densities is more difficult to explain. Previous studies by Culver $(1973 a, 1975)$ indicate that competitive interactions involving $C$. recurvata and L. usdagalun caused changes in the distribution of $C$. antennatus. The different results obtained in the present study may be due to the multifactorial approach in which the relative importance of each of five environmental parameters on the overall distribution of $C$. antennatus was examined. Localized, statistically, nonsignificant shifts in C. antennatus distribution were observed in the present investigation apparently due to competitive interactions. Culver (1973a) indicated that intense competition from $L$. usdagalun nearly excludes $C$. antennatus in caves in Lee Co., Virginia, and evidence for this competitive interaction was found in Gallohan No. 2 Cave where sample sites con-

Table 4. Substrates most commonly sampled in each cave compared with substrates on which the greatest number of $C$. antennatus were observed. Significance of amphipod numbers between the two substrate categories determined by t-test.

\begin{tabular}{lccc}
\hline Cave & $\begin{array}{c}\text { Most common } \\
\text { substrate }\end{array}$ & $\begin{array}{c}\text { Substrate with greatest } \\
\text { amphipod density }\end{array}$ & $\mathrm{P}$ \\
\hline Cope & large gravels & large gravels & $>.05$ \\
Gallohan No. 2 & small gravels & small gravels & $>.05$ \\
Spangler & bedrock & large gravels & $<.001$ \\
Sweet Potato & mud & mud & $>.05$ \\
Molly Wagle & mud & mud & $>.05$ \\
Roadside No. 1 & mud & mud & $>.05$ \\
\hline
\end{tabular}


taining L. usdagalun were devoid of amphipods and C. antennatus population densities are quite low (Table 2).

Substrate type was the only factor found to effect C. antennatus distributions, both in individual caves and in the two subterranean habitats (Table 3). In all caves but Spangler, the selection of a particular substrate does not appear to be an active process, as $C$. antennatus is found in greater numbers on the most common substrate observed (Table 4). In Spangler Cave, however, amphipods were most frequently found in large gravel sections rather than on the more common bedrock areas (Table 4). The apparent active substrate selection by $C$. antennatus in this cave may be associated with the distribution of the isopod C. recurvata. In Spangler Cave larger numbers of $C$. recurvata were observed on bedrock areas than in large gravel sections (t-test, $\mathrm{n}=38, \mathrm{t}=20.0, \mathrm{P}<.001$ ), suggesting that $C$. antennatus has been competitively excluded from this particular substrate. The appearance of a substrate shift in only Spangler Cave may be due to the large population of C. recurvata (Fig. 1).

Amphipod predators, such as the salamander Gyrinophilus porphyriticus, have also been observed to influence the distribution of C. antennatus (Culver, 1975), but were not included in the present analysis because of their small numbers (Dickson, 1977a). Other environmental factors, such as dissolved oxygen, water temperature and intra-specific interactions, may also be of importance in population distributions.

In summary, population distributions of $C$. antennatus were found to be affected by substrate type in two different cave habitats. Population distributions do not appear to be significantly related to other environmental parameters which differ markedly between the pool and stream habitats, indicating the retention of ecological flexibility in this troglobitic species.

\section{ACKNOWLEDGMENTS}

I am grateful to Dr. John R. Holsinger for assistance and advice throughout this study and for reviewing the manuscript. I aso wish to thank George D. Corbett, Jean Dickson, James A. Estes, Stephen W. Hetrick and David Wapinski for their help in the field.

\section{RESUME}

Les densités de population et les facteurs influençant la distribution $d u$ Crustacé Amphipode troglobie Crangonyx antennatus ont été examinés dans deux types d'habitats aquatiques distincts. Pendant un an, on a fait des observations dans 6 cavernes du Comté de Lee, Virginie, (U.S.A.), dont trois avec des mares à fond boueux et les trois autres avec un ruisseau à fond de gravier, Les habitats dẹ mares montrent une plus grande densité de $C$, antenna. 
tus que ceux des ruisseaux. La densité saisonnièer la plus forte a été remarquée en août. La disponibilité en nourritoure peut être considérée comme le facteur primordial de l'accroissement de densité des populations. On s'est aperçu que la distribution de la population de $C$. antennatus n'avait aucun rapport avec la force du courant, la profondeur de l'eau, les sources de nourriture macro-détritve ou les densités des Isopods dans ces habitats de mares ou de ruisseaux. Il a été observé que la distribution des $C$. antennatus est en relation avec le type de substrat. La sélection du substrat semble passive dans cinq des populations, tandis que dans la dernière des grottes, le choix du substrat semble être influencé par des interactions compétitrices. Le fait que les distributions des populations ne sont pas en relation avec les charactères de l'environnement, $\mathrm{qu}_{i}$ dffèrent remarquablement entre ces habitats, indique que cette espèce troglobie a conservé une certaine souplesse écologique.

\section{REFERENCES}

BARR, A.J., J.H. GOODNIGHT, J.P. SALL and J.T. HELWIG, 1976. A user's guide to SAS 76. SAS Institute, Raleigh, N.C., 329 pp.

CULVER, D.C. 1970. Analysis of simple cave communities: niche separation and species packing. Ecology 51:949-958.

CULVER, D.C. 1971. Analysis of simple cave communities. III Control of abundance. Amer. Midl. Nat. 85:173-187.

CULVER, D.C. 1973a. Competition in spatially heterogeneous systems: an analysis of simple cave communities. Ecology 54:102-110.

CULVER, D.C. 1973b. Feeding behavior of the salamander Gyrinophilus porphyriticus in caves. Int. J. Speleol. 5 369-377.

CULVER, D.C. 1975. Interaction between competition and predation in cave stream communities. Int. J. Speleol. 7:229-245.

DICKSON, G.W. 1975. A preliminary study of heterotrophic microorganisms are as factors in substrate selections of trogolbitic invertebrates. Nat. Speleol. Soc. Bull. 37:89-93.

DICKSON, G.W. 1976. Variation in the ecology, morphology and behavior of the troglobitic amphipod crustacean Crangonyx antennatus Packard (Crangonychidae) from different habitats. Virginia J. Sci. 27:43.

DICKSON, G.W. 1977b. Variation among populations of the troglobitic amphipod crustacean Crangonyx antennatus Packard living in different habitats. I. Morphology. Int. J. Speleol. 9:43-58.

DICKSON, G.W. 1977b. Behavioral adaptation of the troglobitic amphipod crustacean Crangonyx antennatus to stream habitats. Hydrobiologia 56: 17-20.

DICKSON, G.W. 1979. The importance of cave mud sediments in food preference, growth and mortality of the troglobitic amphipod crustacean Crangoyx antennatus Packard (Crangonyctidae). Crustaceana. 36:129-140.

DICKSON, G.W. and P.W. KIRK, Jr. 1976. Distribution of heterotrophic microorgansms in relation to detritivores in Virginia caves. (With supplemental bibliography on cave mycology and microbiology). p. 205-226. In B. C. Parker and M. K. Roane (eds.), The distributional history of the biota of the southern Appalachans. Part. IV. Algae and fungi. University Press of Virginia, Charlottesville, Va.

HARGRAVE, B.T. 1970. The utilization of benthic microflora by Hyalella azteca (Amphipoda). J. Anim. Ecol. 39:427-437.

HOLSINGER, J.R. 1969. Biogeography of the freshwater amphipod crustaceans (Gammaridae) of the central and southern Appalachians. p. 19-50. In P. C. Holt (ed.), The distributonal history of the biota of the southern Appalachians. Part I Invertebrates, Virginia Polytechnic Inst, Press, Blacksburg, Va 
HOLSINGER, J.R. 1972. The freshwater amphipod crustaceans (Gammaridae) of North America Biota of freshwater ecosystems, Identifications manual no. 5, u.s. EPA, 89 pp.

HOLSINGER, J.R., and G.W. DICKSON, 1977. Burrowing as a means of survival in the troglobitic amphipod crustacean Crangonyx antennatus Packard (Crangonyctidae). Hydrobiologia 54:195-199.

KAUSHIK, N.K., and H.B.N. HYNES, 1969. Experimental study on the role of autumn-shed leaves in aquatic environments, J. Ecol. 56:229-243.

MARZOLF, G.R. 1965. Substrate relations of the burrowing amphipod Pontoporeia affinis in Lake Michigan. Ecology 46:586-592.

MARZOLF, G.R., 1966. The trophic position of bacteria and their relation to the distribution of invertebrates. Pymatuning Lab. Field Biol. Spec. Publ. 4:131-135.

MINCKLEY, W.J., and G.A. COLE, 1963. Ecological and morphological studies on gammarid amphipods (Gammarus spp.) in spring-fed streams of northern Kentucky. Occasional Papers C.C. Adams Center for Ecol. studies 10:1-35. 